\title{
Developing a TQM Evaluation Indicators for Rural Tourism in Jordan
}

\author{
Dr. Ismaiel Abuamoud, Associate Professor \\ Department of Tourism Management, The University of Jordan, Amman, 11941 \\ Dr. Khaled Al-bour: Associate Professor \\ Department of Archaeology, The University of Jordan, Amman, 11941
}

\begin{abstract}
The study aims at developing a Total Quality Management model TQM indicator for small businesses in rural touristic businesses in Jordan including (accommodation, travel and services including accessibility, sites, local product information) to support rural planners for the implementation of sustainable tourism in the targeted area. To achieve this aim, the study has conducted four different types of surveys to assess the quality of a provided service from four different prospective, the customers, business owners, the mystery shoppers, and field visit by specialists from the team members. The respondents were asked to rate their opinion about services quality by select from a list which were measured on a five-point Likert scale, with " 5 " indicating "very satisfied" and " 1 " indicating "very dissatisfied. All questions were designed to measure how users, service providers, mystery shoppers, and quality control expert to interpret and evaluate the service quality and obtain insights that measure the service performance and perception against the intended service promise. The results revealed that the overall average of quality of the services ranked between poor and fair
\end{abstract}

Keywords: TQM, Tourism, Service Quality Management,

DOI: $10.7176 / \mathrm{JTHS} / 51-05$

Publication date:October $31^{\text {st }} 2020$

\section{Introduction}

Total Quality Management TQM is an administrative approach for long-term success through customer satisfaction. (Zehira, Ertosunb, Zehir, \& Müceldilli, 2012) All members in the organization participate in improving the procedures, products, services and culture prevailing in the workplace

The quality of service is a measure through the degree to which the level of service provided to the customers meets to their expectations, therefore the provision of a distinguished quality service means matching the actual quality level with the client's expectations or exceeding their expectations (Topalovic, 2015) The importance of quality of service as a basis for achieving excellence has increased, and thus the level of quality of service performance has become one of the competitive tools for building and achieving customer satisfaction and loyalty (Ofori, Boakye , \& Narteh, 2018).

There is no doubt that tourism sector plays a significant role in economy of any country, especially the developing ones. Tourists no longer searches for products only, but searches for solutions to his problems, hence the mission of the institution is no longer to provide products but to find solutions for customers' problems (Font \& McCabe, 2017).

Definitions of tourism deviate from what tourism means to ordinary people than another specialists in economics, socialists, environmentalists, or cultural (Yu, Kim, \& Chen, 2012). From environmental point of view, it improve biodiversity conservation and reduce poverty (Liu, et al., 2012), and creates economic development (A, S, \& Hamzah , 2016), in addition to its impact on social and cultural impact on local communities (Smith \& Ram , 2017). Others define tourism as the activities of persons temporarily away from their usual environment for not more than one year for virtually any activity, except the pursuit of remuneration from within the place visited (Abuamoud, Libbin , Green, \& ALRousan, 2014), (Ghanem , 2017). United States Department of Commerce, Office of Tourism Industries (TI) defines travel and tourism as a sector made up of "a diverse group of industries that supply goods and services purchased by business and other travelers" (Abuamoud, Libbin , Green, \& ALRousan, 2014)

According to the World Tourism Organization, the worldwide arrivals grew by 5\% in 2018 reaching 1.5 billion (UNWTO, 2019). The Middle East attained the highest growth rate, of 8\% (Holland, 2019). Also, it has been estimated that the Middle East will achieve an annual growth rate of 10\% over the period 2019-2020 (UNWTO, 2019). The contribution of the tourism sector in the global economy was about $10.4 \%$ as a percentage of global GDP, 319 million jobs in 2004. These numbers are estimated to reach US \$2 trillion and 305 million jobs in 2019 (WTTC, 2019)

This study aims at developing a TQM model for tourism providers in Jordan through interviews and questionnaires used to collect data from small business service providers in tourism sector from different locations in Jordan. 


\section{Literature review}

Earlier in the 1920s, statistical theory was first applied to product quality control which considered as the origins of Total Quality Management (TQM). Then during the 40s TQM concept has developed by Japanese before it has been developed by Deming, Juran and Feigenbaum between 50s and 80s (BPIR, 2020). (Manthou \& Vlachopoulou, 2001) (Mohammad, 2004), Figure 1. Quality in the tourism industry is defined as the process that meets consumer needs and expectations regarding the products and services at an acceptable price, and to in line with the terms and expectations of the customers, such as safety, security, hygiene, accessibility, transparency, and environmental requirements (Alsrabi, 2013).

Quality has become a critical component that enables businesses to maintain its direction and positions in the industry, especially with the current global development in all fields, and this is why modern thought has taken care of TQM in consideration especially in tourism sector (Erdogan , 2007). TQM has been defined as the integrated form of the organization's business with the goal of achieving quality and continuous development. Productivity through the efforts of all departments (Benavides, García, \& Macarena , 2014). From another dimension, TQM is introduced very important comprehensive management approach through working horizontally across an organization, connecting all employees and departments and extending backward and forward to include all suppliers and customers (Kiran, 2016) (Sadikoglu \& Olcay, 2014)

Since 1980s a tremendous progress in management methods has been evolved especially in fields of operations and production management, and the emergence of quality management has had a clear impact on increasing the efficiency of productive activities in various organizations and customer satisfaction (Blau, Simpson , \& Anderso, 2010). Under globalization and the global trade agreements TQM have causes an intense competition between businesses, only high-quality service providers that fulfill the desires of consumers can survive (Lee \& Hwang, 2011) (Stepanov, Stepanov, \& Vukotić, 2017).

According to the American Society of Quality (ASQ, 2017), TQM can be summarized as an administrative system where organization focused on the requirements of its customers, based on the fact that all employees work to ensure continuous improvement. Strategies, and effective communication are used to integrate quality competence into the organization's culture and activities. The essential elements in total quality management are (Bouranta, Psomas, Suárez, \& Jaca, 2019) (Milosan, 2014) (Bigliardi \& Galati, 2014):

Customer Focus: The customer ultimately determines the quality level. Regardless of what the organization is doing to promote quality improvement, staff training, quality assimilation into the design process, upgrading online systems, reviews, or purchasing process and implementing measurable factors, the customer determines whether the efforts are worthwhile or not.

Comprehensive employee participation: all employees participate in the work to achieve common goals. The employee's full commitment takes place only when fear of the workplace is removed and is empowered within his duties and the administration provides the appropriate environment. Essential procedures, integrated system, strategic direction, continuous improvement, and high quality communication with the customers are all the main elements of TQM.

TQM approach is one of the most important means to achieving excellence in the tourism services (Abuamoud, Ibrahim, \& Alrousan, 2018), for example, some countries have developed quality assurance programs (Simon , Kaosiri, \& Narangajavana, 2019). These programs directed to tourism service providers such as restaurants, hotels, and airlines with special symbol of quality that distinguishes them from other service providers (Widarsyah, Ghiselli, \& Adler, 2016). Another example from the United Arab Emirates, where the Emirate of Dubai seeks to achieve excellence in the field of tourism through developing number of quality standards aiming at providing sustainable tourism (Giampiccoli \& Mtapuri, 2015) (Kotsi \& Michael , 2015). The importance of quality appears in the tourism sector as a service industry and the level of services vary based on different factors such as, human resources which includes; human culture, management, level of education, specialization, training and experience. Secondly the physical, such as specifications and classification and measurement indicators, and thirdly the quality in public services in the destination like, health services, transportation, traffic and general cleaning services, as well as "access services" or something (Thornton, Soriano, \& Urbano, 2011) (Dirani, 2007) (Grenčíková, Vojtovič, \& Gullerová, 2013)

One of the first pioneers in total quality management is Armand V. Feigenbaum who built the foundation stone of the concept of TQM through his book "Total Quality Control." 1958 to 1968 (Weiers, 2008) (Behnam, 2017). In his book "Total Quality Control, Feigenbaum stated that TQC is "the system where quality development, maintenance, and improvement are effectively integrated to ensure production and service at considerably lower costs. This ultimately leads to higher customer satisfaction, which is so critical for all businesses" (Feigenbaum., 1983) which is not far away of the definition of TQM. Also Feigenbaum emphasized on the importance of understanding customers' perception, quality and cost are important and the importance of involving all teams in the process (Feigenbaum, 1983). 


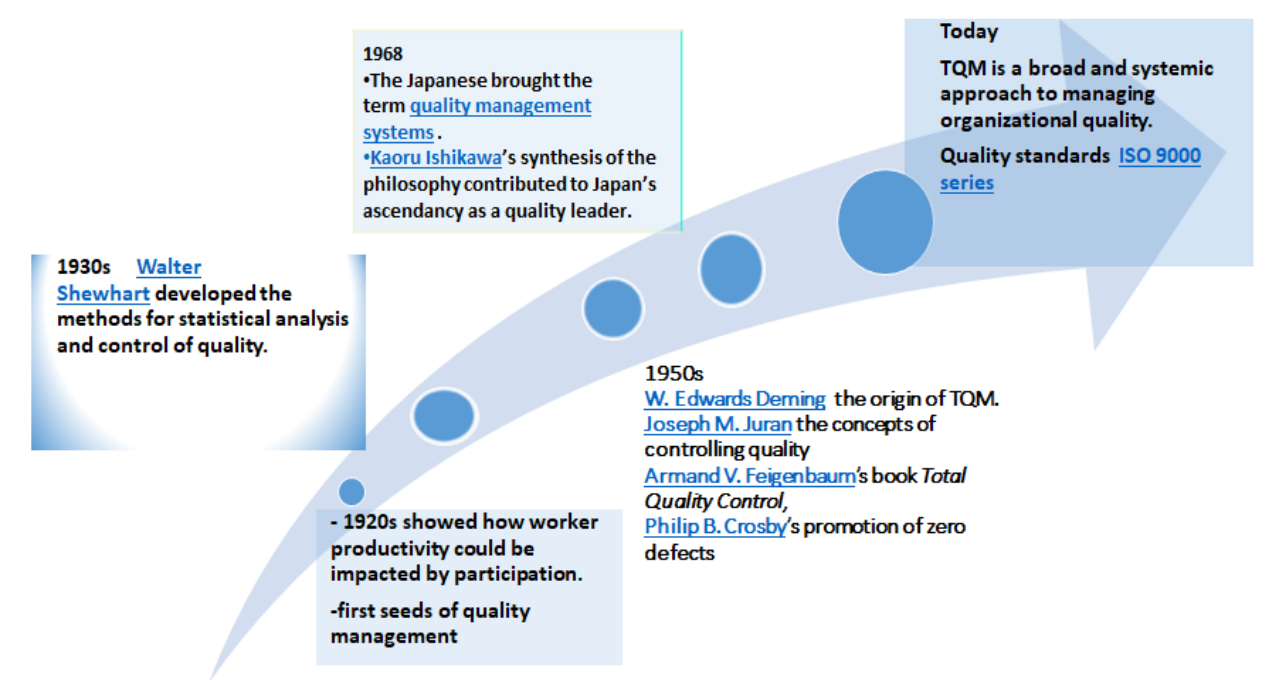

Figure 1Addapted from the Certified Manager of Quality/Organizational Excellence Handbook, Fourth Edition3.

\section{Methods}

The study aims at evaluating and developing a TQM indicators for small businesses in rural touristic businesses in Jordan. To measure, and evaluate the current services quality level in the targeted small businesses, a survey were designed, conducted in two rural touristic site. A questionnaire was developed as a means to collect data from 55 small businesses. The questionnaire consists of (33) questions answered by three groups (Customers, Business Owners, and Mastery Shoppers) focused on four categories (Activities, Employee, Customer Services, and Overall evaluation) table1. The questions focused on the information availability and accuracy, safety and security procedures. The activity section focused on the level of understanding of activities by employees, the development plan, and diversity of the activities. Regarding employees, the questions covered areas such as training needed, performance of employee, evaluation of services, and communication skills. The questions covered the overall of services included questions about the care taken of the customers in general, does the service provided meets customers expectation, and the readiness of service provider to deal with unexpected events or needs. The results of the service provider's survey is expected to help service providers to understanding their current situation in four different areas shown in table1. The respondents were asked to rate their opinion about services quality by select from a list which were measured on a five-point Likert scale, with " 5 " indicating "very satisfied" and " 1 " indicating "very dissatisfied. The data were analyzed on the base of frequency and mean to compare between the answers of the three groups on the four categories.

Table 1categories included in the assessment

Category

Activities

Employee

Customer service

General information

Total number of questions

\section{TQM sub categories}

- Process center

- Integrated system

- Systematic approach

- Tourism employee investment

- Communication

- Continual improvement

- Customer focus

- Fact base-decision

- Services on route

\section{Number of questions}

7

6

8

12 


\section{Results}

\subsection{How to read the results?}

Table 2shows the meaning of each statement in Likert scale and the rank of the service. For example "strongly disagree" equivalent to "poor service", while "Strongly agree" is equivalent to "Excellent service".

Table 2Ranking of services

$\begin{array}{lll}\text { Statement } & \text { Category } & \text { Result /Rank } \\ \text { Strongly Disagree } & 0-0.99 & \text { Poor service } \\ \text { Disagree } & 1-1.99 & \text { Fair service } \\ \text { Neither Agree or Disagree } & 2-2.99 & \text { Good service } \\ \text { Agree } & 3-3.99 & \text { Very good service } \\ \text { Strongly Agree } & 4-5 & \text { Excellent service }\end{array}$

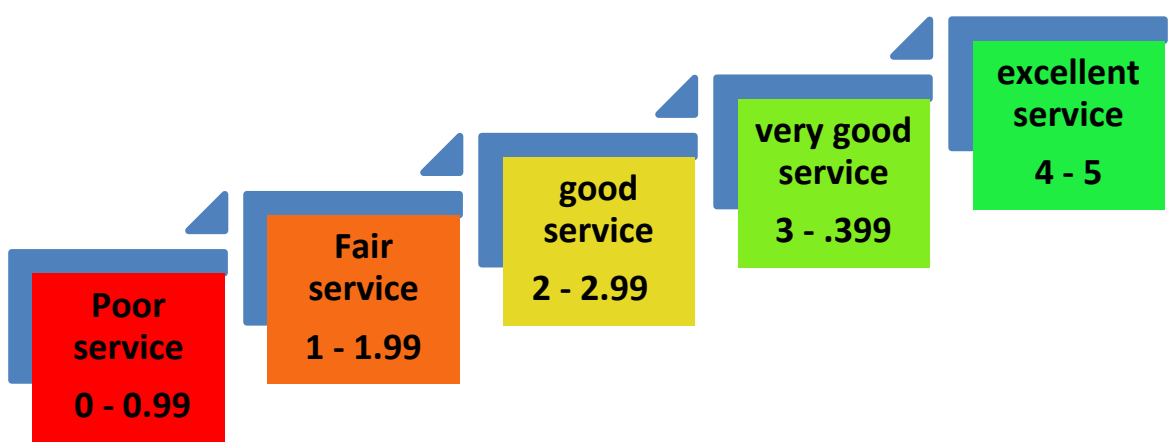

Figure 2Ranking of services

The respondents were asked to rate their opinions on the level of services quality provided by the service providers in the targeted sites. They could select from a list of items which were measured on a five-point Likert scale, with (with " 5 " indicating "very satisfied" and " 1 " indicating "very dissatisfied). Table 2 shows the ranking of the level of services evaluated by the three groups, (Customers, Business Owners, and Mastery Shoppers) The results revealed that, "the ooverall satisfaction by customers about the level of services evaluated as good service with mean at 2.46, while the lowest overall satisfaction was by the business owners when they evaluated their level of services against the indicators they have given and they supposed to be at mean 1.71 which indicated fair level of service, followed by the evaluation by the mystery shoppers with mean at 1.81 . The lowest satisfaction (mean 1.54) which represents the opinion of mastery shoppers with the customer services Table2.

Figure 3 ranking results of the services

\begin{tabular}{|l|c|c|c|c|c|}
\hline Category & $\begin{array}{c}\text { Activities } \\
\text { Mean }\end{array}$ & $\begin{array}{c}\text { Employee } \\
\text { Mean }\end{array}$ & $\begin{array}{c}\text { Customer Service } \\
\text { Mean }\end{array}$ & $\begin{array}{c}\text { Overall evaluation } \\
\text { Mean }\end{array}$ & $\begin{array}{c}\text { Over All } \\
\text { Mean }\end{array}$ \\
\hline Customers & 2.48 & 2.36 & 2.49 & 2.49 & $\mathbf{2 . 4 6}$ \\
\hline Business Owners & 1.81 & 1.68 & 1.65 & 1.71 & $\mathbf{1 . 7 1}$ \\
\hline Mastery Shoppers & 1.81 & 1.81 & 1.54 & 2.10 & $\mathbf{1 . 8 1}$ \\
\hline
\end{tabular}

\subsection{The Overall Action}

Based on the survey results, the service provider must take these actions into considerations through the following steps.

\subsection{TQM Guidelines Check}

The service provider in consultants with the quality expert should be able to decide on which of the TQM guidelines relates to the selected service flaw and try to enforce and/or apply the TQM guideline to it. (TQM Guidelines in table 3)

\subsection{Training Session}

In collaboration with the quality experts, the service provider should be able to attend and/or prepare training sessions that are related to the selected service item. These training sessions should be a chance for the service provider to increase the quality of the selected service item to meet a standardized model that is accepted within the service culture. 


\subsection{The Sub Actions}

Based on the grades of each sub categories, the stakeholder/service provider recommended to take these actions into considerations in-order to improve the quality of each sub category which as a result would improve the overall quality of the service.

Table 4TQM Guidelines and Indicators

\begin{tabular}{|c|c|c|c|c|}
\hline $\begin{array}{l}\text { Grand } \\
\text { total } \\
\text { grade }\end{array}$ & General overview & $\begin{array}{l}\text { Activities within the } \\
\text { service }\end{array}$ & $\begin{array}{l}\text { Employee attitude } \\
\text { and behavior }\end{array}$ & Customer service \\
\hline $0-0.99$ & $\begin{array}{l}\text { 1. Raising awareness } \\
\text { about TQM } \\
\text { 2. Participating } \\
\text { Training Sessions. }\end{array}$ & $\begin{array}{l}\text { 1. Raising awareness } \\
\text { about TQM } \\
\text { 2. Participating } \\
\text { Training Sessions. }\end{array}$ & $\begin{array}{l}\text { 1. Raising awareness } \\
\text { about TQM } \\
\text { 2. Participating } \\
\text { Training Sessions. }\end{array}$ & $\begin{array}{l}\text { 1. Raising awareness } \\
\text { about TQM } \\
\text { 2. Participating } \\
\text { Training Sessions. }\end{array}$ \\
\hline $1-1.99$ & $\begin{array}{l}\text { 1. Applying TQM } \\
\text { Guidelines Check } \\
\text { 2. Developing and/or } \\
\text { participating in } \\
\text { training Sessions. }\end{array}$ & $\begin{array}{l}\text { 1. Applying TQM } \\
\text { Guidelines Check } \\
\text { 2. Developing and/or } \\
\text { participating in } \\
\text { training Sessions. }\end{array}$ & $\begin{array}{l}\text { 1. Applying TQM } \\
\text { Guidelines Check } \\
\text { 2. Developing and/or } \\
\text { participating in } \\
\text { training Sessions. }\end{array}$ & $\begin{array}{l}\text { 1. Applying TQM } \\
\text { Guidelines Check } \\
\text { 2. Developing and/or } \\
\text { participating in } \\
\text { training Sessions. }\end{array}$ \\
\hline $2-2.99$ & $\begin{array}{l}\text { 1. Check TQM } \\
\text { Guidelines Check, } \\
\text { 2. Developing and/or } \\
\text { participating in } \\
\text { training Sessions. }\end{array}$ & $\begin{array}{l}\text { 1. Check TQM } \\
\text { Guidelines Check, } \\
\text { 2. Developing and/or } \\
\text { participating in } \\
\text { training Sessions. }\end{array}$ & $\begin{array}{l}\text { 1. Check TQM } \\
\text { Guidelines Check, } \\
\text { 2. Developing and/or } \\
\text { participating in } \\
\text { training Sessions. }\end{array}$ & $\begin{array}{l}\text { 1. Check TQM } \\
\text { Guidelines Check, } \\
\text { 2. Developing and/or } \\
\text { participating in } \\
\text { training Sessions. }\end{array}$ \\
\hline $3-3.99$ & $\begin{array}{l}\text { 1. Check TQM } \\
\text { Guidelines } \\
\text { 2. Looking for a raw } \\
\text { model } \\
\text { 3. Sustaining the } \\
\text { system. }\end{array}$ & $\begin{array}{l}\text { 1. Check TQM } \\
\text { Guidelines } \\
\text { 2. Looking for a raw } \\
\text { model } \\
\text { 3. Sustaining the } \\
\text { system. }\end{array}$ & $\begin{array}{l}\text { 1. Check TQM } \\
\text { Guidelines } \\
\text { 2. Looking for a raw } \\
\text { model } \\
\text { 3. Sustaining the } \\
\text { system. }\end{array}$ & $\begin{array}{l}\text { 1. Check TQM } \\
\text { Guidelines } \\
\text { 2. Looking for a raw } \\
\text { model } \\
\text { 3. Sustaining the } \\
\text { system. }\end{array}$ \\
\hline $4-5$ & $\begin{array}{l}\text { 1. Keeping on } \\
\text { sustaining the system } \\
\text { 2. Being a model } \\
\text { through collaboration } \\
\text { with other } \\
\text { Stakeholders. }\end{array}$ & $\begin{array}{l}\text { 1. Keeping on } \\
\text { sustaining the system } \\
\text { 2. Being a model } \\
\text { through collaboration } \\
\text { with other } \\
\text { Stakeholders. }\end{array}$ & $\begin{array}{l}\text { 1. Keeping on } \\
\text { sustaining the system } \\
\text { 2. Being a model } \\
\text { through collaboration } \\
\text { with other } \\
\text { Stakeholders. }\end{array}$ & $\begin{array}{l}\text { 1. Keeping on } \\
\text { sustaining the system } \\
\text { 2. Being a model } \\
\text { through collaboration } \\
\text { with other } \\
\text { Stakeholders. }\end{array}$ \\
\hline
\end{tabular}

\section{Conclusion and Recommendation:}

All results of all the surveys can be cross tabulated by matching the co-related items of the each surveys with each other to get a collective understanding of the overall respondents. The cross tabulated results will affect the overall understanding of the qualitative aspect of the offered service for each stakeholder. Tourism local industry should:

- Adopt "Tourism Standards indicators";

- Use a "service charter" which states its commitment in delivering;

- Review progress according to the framework;

- Use feedback from tourists to improve the product;

- Measure the impact of quality initiatives in terms of effectiveness and efficiency;

- Use data and information predicatively and reflectively.

\section{References}

A, H., S, M., \& Hamzah , A. (2016, June ). The Impact of Emotional Solidarity on Residents' Attitude and Tourism Development. (Y. Chen, Ed.) 11(6). doi:https://doi.org/10.1371/journal.pone.0157624

Abuamoud, I., Ibrahim, A., \& Alrousan, R. (2018). Measuring Tourists' Satisfaction and Loyalty: A Perception Approach. Quality Management $\quad$ Journal, $25(2), \quad$ 101-107. doi:https://doi.org/10.1080/10686967.2018.1436352

Abuamoud, I., Libbin, J., Green, J., \& ALRousan, R. (2014). Factors affecting the willingness of tourists to visit cultural heritage sites in Jordan. Journal of Heritage Tourism, 9(2), 148-165. doi:http://dx.doi.org/10.1080/1743873X.2013.874429

Alsrabi, A. (2013). Total Quality Management in Tourism Companies: A Field Study of the Views of a Sample of Top Management in First-Class Hotels in Riyadh. 4(3), 15. doi:DOI: 10.4018/jabim.2013070101 ASQ. (2017). American Society for Quality. Retrieved from American Society for Quality: https://asq.org/ 
Behnam, N. (2017). Principles and Contributions of Total. De La Salle University.

Benavides, C., García, C., \& Macarena , L. (2014). Total quality management, corporate social responsibility and performance in the hotel industry. International Journal of Hospitality Management, 41, 77-87. doi:https://doi.org/10.1016/j.ijhm.2014.05.003

Bigliardi, B., \& Galati, F. (2014). The Implementation of TQM in R \& D Environments. Journal of Technology Management \& Innovation, 9(2). doi:http://dx.doi.org/10.4067/S0718-27242014000200012

Blau, F., Simpson , P., \& Anderso, D. (2010). Continuing Progress? Trends in Occupational Segregation in the United States over the 1970s and 1980s. Feminist Economics, 29-71. doi:https://doi.org/10.1080/135457098338301

Bouranta, N., Psomas, E., Suárez, M., \& Jaca, C. (2019, January). The key factors of total quality management in the service sector: a cross-cultural study. Benchmarking: An International Journal. doi:DOI: 10.1108/BIJ09-2017-0240

BPIR. (2020, April 1). Business Performance Improvement Resource (BPIR). Retrieved April 2, 2020, from https://www.bpir.com/

Dirani, K. (2007). Exploring socio-cultural factors that influence HRD practices in Lebanon. Human Resource Development International, 9(1), 85-98. doi:https://doi.org/10.1080/13678860500523270

Erdogan , K. (2007). Total quality management and business excellence in services: The implications of allinclusive pricing system on internal and external customer satisfaction in the Turkish tourism market. Total Quality Management \& Business Excellence, 857-877. doi:DOI: 10.1080/14783360600595252

Feigenbaum, A. (1983). Total Quality Control. New York · St. Louis · San Francisco · Auckland, USA: McGraw Hill Book. doi:ISBN 0-07-020353-9

Feigenbaum., A. (1983). Total Quality Control. New York: McGraw Hill Book.

Font, X., \& McCabe, S. (2017). Sustainability and marketing in tourism: its contexts, paradoxes, approaches, challenges and potential. 25(7), 869-883. doi:DOI: 10.1080/09669582.2017.1301721

Ghanem, J. (2017, September). Conceptualizing "the Tourist": A critical review of UNWTO definition. Retrieved April 3, 2020, from Universitat de Girona.

Giampiccoli, A., \& Mtapuri, O. (2015). Diversification and Innovation in TourismDevelopment Strategy: The Case of Abu Dhabi. Diversification and Innovation in TourismDevelopment Strategy: The Case of Abu Dhabi https://www.researchgate.net/publication/309039901 Diversification and Innovation in tourism develop ment_strategy_The case_of_Abu_Dhabi

Grenčíková, A., Vojtovič, S., \& Gullerová, M. (2013). Staff qualification and the quality of tourism-related services in the Nitra region. Bulletin of Geography. Socio-economic Series, 21, 41-48. Retrieved from http://versita.com/bgss

Holland, J. (2019). Global tourist arrivals climb $+4 \%$ in first half of 2019, reports UNWTO. The Moodie Davitt Report. Retrieved from https:/www.moodiedavittreport.com/global-tourist-arrivals-climb-4-in-first-half-of2019-reports-unwto/

Kiran, D. (2016). Total Quality Management. Butterworth-Heinemann. Retrieved Aril 2, 2020

Kotsi , F., \& Michael , I. (2015). Planning and Developing 'Destination Dubai' in the Context of the United Arab Emirates (UAE). Retrieved from Research file://C:/Users/ismai/Downloads/10.2015_Kotsi_chapter.pdf

Lee, J., \& Hwang, J. (2011). Luxury marketing: The influences of psychological and demographic characteristics on attitudes toward luxury restaurants. (Elsevier, Ed.) International Journal of Hospitality Management, 30(3), 658-669. doi:https://doi.org/10.1016/j.ijhm.2010.12.001

Liu, W., Vogt, C., Luo, J., He, G., Frank, K., \& Liu, J. (2012, April). Drivers and Socioeconomic Impacts of Tourism Participation in Protected Areas. Plos One, 4(7). doi:doi:10.1371/journal.pone.0035420

Manthou , V., \& Vlachopoulou, M. (2001). Agile Manufacturing Strategic Options. 685-702. doi:https://doi.org/10.1016/B978-008043567-1/50035-8

Milosan, I. (2014). STUDIES ABOUT THE KEY ELEMENTS OF TOTAL QUALITY MANAGEMENT. european scientific journal, 3, 58-62.

Mohammad, T. (2004). Total quality management (TQM): an overview. The Bottom Line, 17(1), 15-19. doi:https://doi.org/10.1108/08880450410519656

Ofori, K., Boakye, K., \& Narteh, B. (2018). Factors influencing consumer loyalty towards 3 G mobile data service providers: evidence from Ghana. Total Quality Management \& Business Excellence, 580-598. doi:DOI: $10.1080 / 14783363.2016 .1219654$

Sadikoglu , E., \& Olcay, H. (2014). The Effects of Total Quality Management Practices on Performance and the Reasons of and the Barriers to TQM Practices in Turkey. Advances in Decision Sciences, 17. doi:https://doi.org/10.1155/2014/537605

Simon , F., Kaosiri, Y., \& Narangajavana, Y. (2019). Quality in Tourism Literature: A Bibliometric Review. Sustainability. doi:http://dx.doi.org/10.3390/su11143859 
Smith, M., \& Ram, Y. (2017). Tourism, landscapes and cultural ecosystem services: a new research tool. Tourism Recreation Research, 42(1), 113-119. doi:DOI: 10.1080/02508281.2016.1253206

Stepanov, S., Stepanov, N., \& Vukotić, N. (2017). Quality Management of Catering Services. Journal of Economic Theory and Practice and Social Issues, 83-96. Retrieved from https://www.ceeol.com/search/articledetail $?$ id $=528856$

Thornton, P., Soriano, D., \& Urbano, D. (2011). Socio-cultural factors and entrepreneurial activity: An overview. International Small Business Journal, 29(2), 105-118. doi:DOI: 10.1177/0266242610391930

Topalovic, S. (2015). The Implementation of Total Quality Management in Order to Improve Production Performance and Enhancing the Level of Customer Satisfaction. Procedia Technology, 1016 - 1022. doi:doi: 10.1016/j.protcy.2015.02.145

UNWTO. (2019). UNWTO. Retrieved from https://www.unwto.org/: https://www.unwto.org/global/pressrelease/2019-01-21/international-tourist-arrivals-reach-14-billion-two-years-ahead-forecasts

Weiers, R. (2008). Introduction to Business Statistics. Thomson Learning.

Widarsyah, R., Ghiselli, R., \& Adler, H. (2016). Quality Assurance in Hospitality and Tourism Higher Education: Administrators' View of ACPHA Accreditation-An Exploratory Study. Journal of Quality Assurance in Hospitality \& Tourism, 18(2), 1-23. doi:DOI: 10.1080/1528008X.2016.1208599

WTTC. (2019). Travel and Tourism World Economic 2019 Impact. World Travel \& Tourism Council. Retrieved April 3, 2020, from https://www.wttc.org/-/media/files/reports/economic-impact-research/regions2019/world2019.pdf

Yu, X., Kim, N., \& Chen, C. (2012). Are you a tourist? Tourism definition from the tourist perspective. Tourism Analysis, 17, 445-457. doi:DOI: http://dx.doi.org/10.3727/108354212X13473157390687

Zehira, C., Ertosunb, Ö., Zehir, S., \& Müceldilli, B. (2012). Total Quality Management Practices' Effects on Quality Performance and Innovative Performance. Procedia - Social and Behavioral Sciences, 273 - 280. doi:doi: $10.1016 /$ j.sbspro.2012.04.031 